\title{
Research on the training and management of young teachers in Agricultural Colleges
}

\author{
Dichen Shen \\ Jilin Agricultural University, Jilin, Changchun, 130118 China \\ 781911388@qq.com
}

\begin{abstract}
Young teachers are the main force of the future development of higher education, which plays an important role in higher education. Therefore, it has become an important task to strengthen the cultivation of young teachers in Colleges and universities. According to the problems existing in the current college youth teachers, the university should start with the methods of teachers' morality construction, teaching and research ability, and the incentive mechanism, and strengthen the cultivation of young teachers.
\end{abstract}

Keywords: Agricultural Colleges and universities; young teachers; training; management model.

\section{Introduction}

In recent years, with the rapid development of higher education, a large number of young intellectuals to join the ranks of teachers have become a new force in Colleges and universities. The quality of young teachers directly affects the level of higher education. Therefore, we must pay attention to the cultivation of young teachers in Colleges and universities, and establish high-quality young teachers.

\section{The significance of the cultivation of young teachers in Colleges and Universities}

(1) The development of Higher Education

Young teachers are the main force in the future development of higher education. It is the important mission of inheriting and developing the fine tradition and creating the future career. The growth of young teachers directly influences the success and failure of higher education and higher education. Therefore, it is important to strengthen and pay attention to the cultivation of young teachers in Colleges and universities.

(2) Conducive to promoting sustainable development in Colleges and Universities

Young teachers are the future of the University, is the hope of education. The teaching level of young teachers in Colleges and universities is of great strategic significance to improve the teaching level of the whole school and promote the sustainable development of colleges and universities. To cultivate a high quality and ability of teachers is the need to realize the development of the school.

(3) Conducive to the growth of individual teachers

Young teachers can grow rapidly, has become an important factor restricting the development of colleges and universities. In the face of increasingly fierce competition, on the one hand, the young teachers themselves should keep on working hard and quickly adapt to the environment. On the other hand, the university should carry out effective training to young teachers in a timely manner, improve their overall quality.

\section{The problems of the youth teachers in Colleges and Universities}

(1) The professional ethics and responsibility consciousness need to be strengthened

Teachers' morality directly influences the quality of the cultivation of talents. Influenced by a few bad atmosphere, part of the young teachers' ideological level is not high, lack of enough dedication spirit, to the cause of education lack due sense of responsibility and mission, only to meet with the completion of the teaching task, the lack of students with the necessary communication. 
(2) Lack of teaching experience, the teaching effect is not high

Most young teachers can't stimulate students' interest because of lack of teaching skills and experience. The teaching effect is not ideal. There are some young teachers lack of patience, not in accordance with the requirements of the teaching plan to prepare seriously, to explain the content is too general, over reliance on multimedia courseware teaching, imparting knowledge of the lack of transition, teaching quality is difficult to guarantee.

(3) The scientific research consciousness is weak, the scientific research level is not high

Some young teachers in Colleges and universities have not been trained in scientific research ability, and scientific research consciousness is relatively weak. Some teachers engaged in scientific research only in order to meet the scientific research assessment or assessment. Lack of scientific research experience of young teachers, through their own efforts to strive to the scientific research projects, more difficult to have a big breakthrough in scientific research, there is a big challenge in the academic research.

\section{Strengthen the cultivation of young teachers in Colleges and Universities}

(1) Strengthening the moral construction of young teachers

To strengthen the moral construction of young teachers in Colleges and universities is a long-term basic project. Effect of young teachers' spirit and work attitude has influence character by environment for students. To regularly convene a forum on ethics education, Youth Teacher Ethics Forum organized activities, so that young teachers to fully exchange and learning. At the same time, the youth teacher professional ethics as an important content of the assessment, through the students, colleagues, leadership and the way of the combination of the young teachers in the evaluation, strict implementation of the teacher's morality, one vote veto system".

(2) Lead to improve the teaching ability of young teachers

To strengthen the cultivation of young teachers' teaching ability is of great significance to improve the quality of young teachers' professional quality. Establish training mechanism. Most young teachers are lack of theoretical knowledge and practical skills of higher education, the school should do a good job on the training of young teachers' education theory, professional ethics and other basic knowledge. Establish the guidance system of teachers. For sex for young teachers to arrange the old, rich experience in teaching teachers as the instructor, give full play to the old teacher mentoring role, to help them overcome the difficulties encountered in the process of teaching. Establish teaching supervision system. To set up a specialized teaching supervision team, to help young teachers to find out the problems and to propose some suggestions for improvement. Fourth, improve the teaching inspection system. Young teachers in teaching a year later, I apply to the Institute, the Institute of organization of the relevant experts to attend lectures. After the acceptance of qualified, the school issued a certificate of acceptance; the acceptance of non-qualified teachers should be targeted to make recommendations, and related training.

(3) Improve the scientific research level of young teachers

Strengthen the research support for young teachers, and effectively improve the scientific level of young teachers. Should not regularly conduct scientific research capacity of young teachers training, and create a strong atmosphere of their active participation in scientific research. Increasing the investment of young teachers' research funds, supporting and encouraging young teachers to carry out scientific research, mobilize the enthusiasm of young teachers' scientific research, and help solve the difficulties encountered in scientific research. The guidance of scientific research projects, and the research methods, policies, etc. In the university project reporting to young teachers tilt, young teachers in training scientific research ability and encourage them to apply for a higher level of the project.

(4) Pay attention to the continuing education of young teachers

Colleges and universities should focus on cultivating the development potential of young teachers, to create a conducive environment for young teachers to continue education. Actively promote the 
degree of young teachers, to select outstanding young teachers to apply for doctoral students. Actively carry out academic exchanges and training, there are plans to select outstanding young teachers to the domestic and foreign colleges and universities to conduct academic exchanges, learning to visit, to encourage them to participate in a high level of academic meeting, improve academic vision. Encourage young teachers to take active part in social practice. School to for young teachers to enterprises and business practices to create good conditions, sending young teachers' attachment to the enterprises and institutions to exercise, and closely combined with the teaching and scientific research and practical work, improve the ability of teachers' teaching and scientific research.

\section{Summaries}

Universities should establish practical and feasible competitive incentive mechanisms to promote outstanding young teachers come to the fore. To create a good atmosphere for fair competition, through a variety of measures, such as the implementation of the "backbone teachers training program", carry out the "top ten young teachers" all kinds of awards poll, recognition of the performance of the outstanding young teachers in teaching and research, fully carry forward the exemplary role, more young teachers to achievements in teaching and scientific research, enhance self-confidence and sense of honor, positive work performance get maximum play.

Colleges and universities should realize the importance of the cultivation of young teachers, create a good environment for the development of young teachers, establish and improve the mechanism to promote the development of young teachers.

\section{Reference}

[1] Chi Yaodan, Wang Chao, Wang Ronghui, from the University of Electronic Design Contest to talk about the cultivation of young teachers in Colleges and universities, the Jilin Normal University Journal: Natural Science Edition, 2008

[2] Wang Weizhong, a new mechanism for the development of young teachers in Colleges and universities, Journal of Ningbo University of Technology, 2007

[3] Yao Binghua, Li Junlin, a talk on the cultivation of young teachers' experimental skills, "experimental technology and management", 2008

[4] Li Xiaojing, an effective way to cultivate young teachers in Colleges and universities of Liu Xiaodan: the young teacher's tutorial system, the scientific and technological information: scientific research, 2007

[5] Tian Yan, on strengthening the culti Shen vation of young teachers in Colleges and universities, "Chinese Education Innovation Herald", 2008

[6] Xu Xiaoming, Liu Jing, edge over, the life of young teachers in Colleges and universities, development status and interests of the demands of investigation and countermeasures research, Journal of Hebei University of Technology: Social Science Edition, 2010

[7] Fu Junjun. Research on the cultivation of young teachers in Colleges and universities [j]. Journal of Wuxi Institue of Commerce, 2009 (9).

[8] Yang Yun, Liu Fugang, the exploration and thinking of the young teacher's tutorial system in Colleges and universities [j]. Modern distance education, 2011 (9). 